\title{
Development of Modern Railway Bogie for Broad Track Gauge - Bogie Frame Assessment
}

Pavol Št’astniak ${ }^{1}$, Lukáš Smetanka ${ }^{1}$, Marián Moravčík ${ }^{2}$

${ }^{1}$ Faculty of Mechanical Engineering, University of Žilina, 01026 Žilina. Slovak Republic. E-mail: pavol.stastniak@fstroj.uniza.sk, lukas.smetanka@fstroj.uniza.sk,

${ }^{2}$ Tatravagónka Inc., Štefánikova 887/53, 05801 Poprad. Slovak Republic. E-mail: marian.moravcik@tatravagonka.sk.

This article is belonging to the publication series, which we published in the previous issues of this journal and there are described the most important and innovative research and development design solutions and computational procedures as part of European structural funds project. The main object of article is the strength test of new design of freight bogie frame through FEM analysis. For the calculation of the analyzed parts of the bogie through finite element the program ANSYS was used. Results of calculations prove, that new designed construction of the bogie frame satisfies strength conditions.

Keywords: Stress Analysis, Bogie Frame Verification, Computer Tools.

\section{Acknowledgement}

This paper was created in accordance to the processing of the project "RAILBCOT - RAIL Vehicles Brake COmponents Test Stand", ITMS Code 26220220011 based on the support of Research and Development Operational Program co-financed from EU sources. The work was also supported by the project No. APVV-0842-11: "Equivalent railway operation load simulator on the roller rig".

Research-Educational Centre of Rail Vehicles (VVCKV)

This paper was created in accordance to the processing of the project "Development of two types of freight wagons with bogies for non-standard wheelbase or track wheelset, complying with the criteria for interoperability, Environmental Issues, safety and reliability ", ITMS Code 26220220070 based on the support of Research and Development Operational Program co-financed from EU sources.

\section{References}

[1] ANSYS, user guide (part of the program package).

[2] DIŽO, J., STEIŠŪNAS, S., BLATNICKÝ, M. (2016). Simulation analysis of the effects of a rail vehicle running with wheel flat. In: Manufacturing technology: journal for science, research and production. - ISSN 1213-2489. - Vol. 16, No. 5 (2016), pp. 889-896.

[3] DIŽO, J., BLATNICKÝ, M. (2016). Computer analysis of a wagon bogie running with a flexible frame. In: RAILCON'16: XVII scientific-expert conference on railways, Niš, Serbia. - Niš: Faculty of Mechanical Engineering, 2016. - ISBN 978-86-6055-060-8. pp. 37-40.

[4] EN 13749 (2011). Railway applications - Wheelsets and bogies - Method of specifying the structural requirements of bogie frames. European Committee for Standardization.

[5] EN 10 025-2 (2005). Hot rolled products of structural steels. Part 2: Technical delivery conditions for non-alloy structural steels

[6] FABIÁN, P., GERLICI, J., MAŠEK, J., MÁRTON, P. (2013). Versatile, efficient and long wagon for intermodal transport in Europe. In: Communications: scientific letters of the University of Žilina. ISSN 1335-4205. Vol. 15, no. 2 , p. $118-123$.

[7] GERLICI, J. et al. (2016). Experimental rigs for wheel/rail research. In: Manufacturing technology: journal for science, research and production. - ISSN 1213-2489. - Vol. 16, No. 5 (2016), pp. 909-916.

[8] GERLICI, J., LACK, T., HARUŠINEC, J. (2013). The Test Stand Load Modulus Implementation for the Realistic Railway Operation in the Laboratory Conditions. In: Manufacturing technology: journal for science, research and production. - ISSN 1213-2489. - Vol. 13, No. 4 (2013), pp. 444-449.

[9] GERLICI, J., LACK, T., HARUŠINEC, J. (2015). Loading collectives for experimental research on the test stand RAILBCOT. In: Dynamics of rigid and deformable bodies 2015, Ústi nad Labem, Czech Republic: University J. E. Purkyně. ISBN 978-80-7414-914-6. - CD-ROM, [12] p. 
[10] GERLICI, J., LACK, T. (2015). Rail vehicle dynamics properties investigation by means of simulation computations. In: Dynamics of rigid and deformable bodies 2016, Ústi nad Labem, Czech Republic: University J. E. Purkyně. ISBN 978-80-7561-016-4. - CD-ROM, [17] p.

[11] KALINČÁK, D. (2015). Modern design of freight bogies. In: Technológ. - ISSN 1337-8996. Vol. 7, No. 2 (2015), pp. 76-81.

[12] LACK, T., GERLICI, J., MAŇUROVÁ, M. (2016). Freight car bogie properties analysis by means of simulation computations. In: Manufacturing technology: journal for science, research and production. - ISSN 1213-2489. Vol. 16, No. 4 (2016), pp. 733-739.

[13] SVOBODA, M., SOUKUP, J. (2013). Dynamic Measurement of Four-Axle Railway Wagon. In: Manufacturing technology: journal for science, research and production. - ISSN 1213-2489. - Vol. 13, No. 4 (2013), pp. 552558.

[14] VEL-WAGON Consortium (2011). Devilerable Report 1.1: State of the art and concept drafting.

Copyright (C) 2017. Published by Manufacturing Technology. All rights reserved. 